\title{
Interfaces entre os padrões de desenvolvimento e a extensão rural brasileira
}

\author{
Interfaces between development patterns and brazilian rural extension
}

\author{
Márcio Maltarolli Quidá1
}

\begin{abstract}
Resumo
Este artigo tem como objetivo analisar os padrões de desenvolvimento frente aos modelos adotados de extensão rural em sua recente trajetória institucional no Brasil. Por meio de pesquisa bibliográfica, pretende investigar as interfaces entre as macrodefinições políticas e as orientações filosóficas para a extensão rural brasileira oriundas das políticas públicas. Conclui-se que as mudanças do enfoque na política de extensão rural, refletidas nas legislações, orientações filosóficas e base material, acompanharam os padrões de desenvolvimento, estreitamente influenciados pela conjuntura internacional e pelas sucessivas rupturas institucionais no Brasil, do assistencialismo ao difusionismo, passando pelo vácuo institucional e deste ao ensaio de uma política voltada a educação integral, libertadora e humanista.
\end{abstract}

Palavras-chave: Extensão rural. Desenvolvimento rural. Assistencialismo. Difusionismo.

\begin{abstract}
This article aims to analyze patterns of development in relation to the models adopted for rural extension in its recent institutional trajectory in Brazil. Through a bibliographical research, it intends to investigate the interfaces between the political macrodefinitions and the philosophical orientations for the Brazilian rural extension from the public policies. It is concluded that the changes in the focus on rural extension policy, reflected in legislation, philosophical orientations and material basis, accompanied the patterns of development, closely influenced by the international conjuncture and successive institutional ruptures in Brazil, from assistance to diffusionism, through institutional vacuum and from this to the test of a policy focused on integral, liberating and humanistic education. Keywords: Rural extension. Rural development. Assistance. Diffusionism.
\end{abstract}

\section{Introdução}

O presente artigo tem como objetivo analisar os padrões de desenvolvimento frente aos modelos adotados de extensão rural em sua recente trajetória institucional no Brasil. Em síntese, pretende investigar as interfaces entre as macrodefinições políticas e as orientações filosóficas para a extensão rural brasileira oriundas das políticas públicas.

\footnotetext{
${ }^{1}$ Doutorando em Política Social pela Universidade Federal Fluminense. Atualmente é professor do Instituto Federal de Educação, Ciência e Tecnologia do Sul de Minas - Campos Muzambinho E-mail: maltarolli26@gmail.com
} 
A temática desenvolvimento é objeto de acaloradas divergências teóricas acerca de seu escopo e abrangência, particularmente porque seu uso foi moldado ao longo da história para incutir caráter inquestionável as narrativas que garantiriam aos operadores a consecução de seus objetivos. Para Esteva (2000), o uso da expressão desenvolvimento pela maioria das pessoas significa exatamente o contrário daquilo que elas querem dizer, pois o senso comum realça os aspectos estritamente relacionados ao crescimento econômico. Para o autor, a expressão foi indevidamente apropriada, especialmente no fim da segunda guerra mundial, quando os Estados Unidos despontavam como uma potência ao centro do mundo e precisavam deixar clara essa posição para consolidar essa hegemonia e torná-la perene. A origem do imbróglio está situada no uso distorcido da metáfora que decorre da linguagem coloquial, onde o desenvolvimento compreende o processo pelo qual são liberadas as potencialidades de um objeto ou organismo, para que esse alcance sua forma plena. Tal metáfora foi apropriada para sublimar as reais finalidades do desenvolvimento e, mais tarde, seu programa.

À imagem e semelhança, a "extensão" enquanto política pública também sempre esteve imersa em uma contenda semântica, especialmente na disputa histórico-política de seu campo associativo. Enquanto o "desenvolvimento" pode servir à lógica excludente do determinismo econômico, partindo da conotação com as expressões crescimento, evolução, maturação, modernização; sua visão holística parte da compreensão multiforme, acolhendo as dimensões econômica, social, política, ambiental, demográfica etc. Por sua vez, a análise do verbete "extensão" pressupõe transmissão e entrega (FREIRE, 1983). Assim, "extensão rural" significa levar conhecimentos sobre práticas agrícolas e de bem-estar social para os agricultores, compreendendo o produtor como um depositário de saberes. A análise rigorosa da expressão nos impede a construção de uma acepção holística. Mas enquanto política pública, pode servir as duas lógicas de desenvolvimento apresentadas.

A política de extensão rural é estudada como política de desenvolvimento rural, não obstante Veiga (2000) inferir que o desenvolvimento rural não existe como fenômeno concreto e separado do desenvolvimento urbano. Segundo o autor, por ser o desenvolvimento um processo complexo, muitas vezes se recorre ao recurso mental de simplificação, estudando separadamente o desenvolvimento econômico; ou, como propõe, estudar separadamente o lado rural do desenvolvimento.

No campo de estudo da Sociologia Rural essa proposição está presente, o que nos impõe a tarefa de promover a necessária desambiguação das expressões equivocadamente utilizadas de forma intercambiável. Navarro (2001) define desenvolvimento rural como o conjunto de ações previamente articuladas, especialmente pelo estado nacional e níveis subnacionais, para induzir mudanças em um 
ambiente rural (não necessariamente agrícola) ${ }^{2}$, visando melhorar o bem-estar social das populações rurais. Assim, a expressão desenvolvimento agrícola compreende exclusivamente as condições materiais da produção, no sentido estritamente produtivo, incidindo por exemplo sobre área plantada, níveis tecnológicos etc. Outra expressão importante é o desenvolvimento agrário. Corresponde as interpretações acerca do mundo rural, estudando as mudanças sociais e econômicas no longo prazo, tais como a posse e o uso da terra, os conflitos para sua obtenção ou as relações de trabalho e subordinação. Por conseguinte, a dimensão agrária do desenvolvimento contempla o viés agrícola e as complexas relações entre os sujeitos sociais e o ambiente. A expressão desenvolvimento rural sustentável surgiu, segundo o autor, para acrescentar o viés ambiental, oriundo da análise dos impactos da atividade agrícola. Por fim, desenvolvimento local refere-se à adoção de estratégias de desenvolvimento que consideram a heterogeneidade espacial do território.

Outro importante aspecto a se considerar refere-se as motivações do Estado para incorporar em sua agenda, políticas, programas e ações voltados ao desenvolvimento rural. Schneider (2010) propõe duas possibilidades de resposta a esta indagação: na primeira delas, a agenda reflete as demandas sociais e são incorporadas pela pressão de atores, movimentos sociais e instituições envolvidas na dinâmica. Outra possibilidade, de maior ocorrência segundo o autor, seria a temática adentrar a agenda através de programas elaboradas ex ante pelos tecnocratas estatais.

Em busca da mesma resposta, Rodrigues (1997) analisou o conceito de seletividade de políticas públicas no Estado capitalista, trabalhado por Claus Offe, no contexto do deslocamento de ênfase nas definições da política de extensão rural no Brasil. Em seu trabalho, o autor construiu um modelo teórico interpretativo para explicar a seletividade classista da política de extensão rural, fundada na antinomia funcional da acumulação capitalista e sua legitimação social, que o Estado busca incessantemente conciliar. A acumulação refere-se ao aparato legal do Estado que permite e impulsiona a acumulação privada e afasta ameaças potenciais que possam interferir no processo, manifestando-se através das políticas públicas, especialmente as macroeconômicas e setoriais; os gastos do governo e o aparato legal que sustenta a propriedade privada, a ordem vigente e as relações entre capital e trabalho. Por outro lado, a legitimação representa a necessidade do ordenamento político de ser aceito pela sociedade, para garantir base de apoio e a reprodução do sistema.

\footnotetext{
${ }^{2}$ Graziano; Del Grossi; Campanhola (2005) utilizam a expressão "novo rural” para caracterizar as modificações estruturais das relações urbano-rurais percebidas nas duas últimas décadas do século XX. Para os autores, o novo rural é o ambiente onde se fazem presentes atividades não agrícolas, decorrentes das necessidades dos seus habitantes, além da agropecuária baseada em commodities e fortemente ligada às agroindústrias e de um conjunto de "novas" atividades agropecuárias, impulsionadas por nichos especiais de mercados.
} 
Navarro (2001) estabelece marcas temporais para as noções de desenvolvimento rural, delimitando-os em dois períodos: o primeiro deles com origem no pós-segunda guerra mundial, perdurando até fins década de 1970, quando os paradigmas da revolução verde impulsionaram um modelo de desenvolvimento hegemônico em todo planeta, focado na obtenção de super safras através do ímpeto modernizante oriundo do surgimento das novas tecnologias, rompendo drasticamente com o passado em nome da racionalidade produtiva, mercantilizando a vida social e tornando o padrão de vida rural subordinado ao urbano. O segundo período, iniciado a partir da década de 1990, teve como marca um complexo conjunto de processos sociais e econômicos associados usualmente à expressão "globalização", denominado neoliberalismo.

Para atingir os objetivos deste trabalho, os eventos serão apresentados em três períodos distintos que, no entendimento particular deste autor, melhor caracterizam a interface entre desenvolvimento rural e extensão e complementam os fatos ocorridos. Além dos dois já citados, apresenta-se a análise dos fatos compreendidos entre os anos de 2003 e 2016, a partir da formulação da Política Nacional de Assistência Técnica e Extensão Rural (PNATER) ao término dos governos do Partido dos Trabalhadores (PT). Na investigação das interfaces e seus desdobramentos, adota-se a abordagem cognitiva de análise de políticas públicas, especialmente as elaborações de Pierre Muller (2008), Bruno Jobert (1987) e Ève Fouilleux (2011), disponíveis em Grisa e Schneider (2015). Os autores destacam o papel das ideias na formulação das políticas públicas, sendo as crenças e representações de mundo dos atores públicos e privados envolvidos o ponto de partida que permite a percepção dos problemas e a construção de possíveis respostas. $\mathrm{Na}$ abordagem, três conceitos (em ordem decrescente de complexidade) são fundamentalmente importantes: referencial global, referencial setorial e referencial de política pública. "O referencial global refere-se a um quadro geral de interpretação do mundo, superando os limites de um setor, de um domínio ou de uma política" (MULLER, 2005 apud GRISA; SCHNEIDER, 2015, p. 22). É em torno do referencial global que são hierarquizadas as diferentes representações setoriais, circunscritas à um setor e refletidas em um conjunto de questões ou problemas associados de maneira mais ou menos institucionalizada a certas populações ou temas. A relação entre os referenciais global e setorial, abstratos em sua essência, permite a construção de uma representação concreta da realidade sobre a qual pretende-se intervir: o referencial de políticas públicas, quando as ideias se transformam em ações.

As seções seguintes discorrem, em cada um dos três períodos delimitados, acerca do referencial global, aceito aqui como a análise da noção geral de desenvolvimento resultante das motivações, relações de força e objetivos políticos dos diferentes atores envolvidos; do referencial setorial de desenvolvimento rural, intrinsicamente ligado às concepções globais e, por fim, do aparato 
legal, orientações filosóficas e base material resultantes do referencial de políticas públicas. Nas considerações finais, apresenta uma síntese explicativa que correlaciona os modelos de extensão frente aos referenciais global, setorial e de políticas públicas.

\section{Do assistencialismo ao difusionismo: Padrões estadunidenses que influenciaram o Brasil}

Os pesquisadores da historiografia stricto sensu da extensão rural compreendem os fatos ocorridos entre 1948 e 1985 em dois períodos, sendo o primeiro deles iniciado em 1948, com a criação da ACAR-MG e interrompido em 1962, pouco antes do golpe civil-militar que instaurou uma ditadura no Brasil. Certamente ocorreram mudanças peremptórias no modelo e nas orientações filosóficas nessa transição, em parte creditada aos planos governamentais, em outra, pelos novos paradigmas tecnológicos. Contudo, em busca do rigor analítico e da delimitação deste trabalho, a tese que aqui se apresenta é que os fatos ocorridos na década de 1950, particularmente os relacionados ao cenário externo, foram preparatórios para as duas décadas seguintes e pertencentes à mesma noção de desenvolvimento.

O padrão de desenvolvimento deste período foi marcado por uma ideologia da modernização de amplitude global, consubstanciada pela evolução da química e da biologia aplicada à agropecuária. A "Revolução Verde", como foi denominado o período, consistiu na pesquisa e desenvolvimento de sistemas de produção agrícola para a incorporação de pacotes tecnológicos de suposta aplicação universal, que visavam o incremento da produtividade em distintas situações ecológicas. Seu marco histórico foi o acordo entre o Ministério da Agricultura do México e a Fundação Rockefeller, em 1943, visando o aumento da produtividade do milho, trigo e feijão. A expressão "pacote tecnológico", expressão recorrente na literatura para designar característica central do modelo, não designava uma simples metáfora. Dois pesquisadores mexicanos envolvidos com o melhoramento genético tiveram a ideia de reunir em um pacote as sementes e demais insumos necessários para o plantio de uma área conhecida. Logo estes pacotes passaram a ser produzidos pelos governos e vendidos em larga escala (MATOS, 2010).

Este marco desvela um personagem central para o objeto deste trabalho: Nelson Rockefeller, membro de uma tradicional família detentora de empresas dedicadas à exploração e comercialização do petróleo, fabricação de máquinas agrícolas, fertilizantes e produção de sementes. Nelson também 
foi um político influente ${ }^{3}$, especialmente no Governo do Presidente dos Estados Unidos, Harry S. Truman, quando atuou na concepção do programa Point Four, que recebeu esse nome por se tratar do quarto objetivo da política externa apresentado em seu discurso inaugural, em 20 de janeiro de 1949. O objetivo era conquistar "corações e mentes" no mundo em desenvolvimento, durante a guerra fria, através de programas de assistência técnica (COLBY; DENNETT, 1998; OLIVEIRA, 1999). No mesmo discurso, o recém-empossado presidente estadunidense usou a expressão "subdesenvolvimento", outorgando novo significado histórico-político ao conceito de desenvolvimento, para discreta ou inadvertidamente referir-se à era da hegemonia norte-americana.

É preciso que nos dediquemos a um programa ousado e moderno que torne nossos avanços científicos e nosso progresso industrial disponíveis para o crescimento e para o progresso das áreas subdesenvolvidas. $\mathrm{O}$ antigo imperialismo - a exploração para lucro estrangeiro- não tem lugar em nossos planos. O que imaginamos é um programa de desenvolvimento baseado nos conceitos de uma distribuição justa e democrática (ESTEVA, 2000, p. 59-60)

O Presidente Truman não foi o criador da palavra. Não obstante, para Esteva (2000), foi o responsável pela mesma ter sido universalmente aceita no mesmo dia, criando uma nova percepção do "eu" e do "outro" ao conferir a condição de subdesenvolvidas à dois bilhões de pessoas, subvertendo duzentos anos de construção social do significado de desenvolvimento proposto por Marx para atender aos propósitos hegemônicos dos Estados Unidos e sua luta contra o comunismo.

As ações previstas no programa Point Four, antes de serem sistematizadas pelo governo Truman, já estavam no rol da American International Association for Economic and Social Development ${ }^{4}$ (AIA), associação filantrópica fundada em 1946 por Nelson Rockefeller para promover assistência técnica em agricultura na Venezuela e no Brasil. Por esse motivo, é um equívoco atribuir a ação de Nelson Rockefeller na Extensão Rural à uma ação do governo americano. Mais tarde, entre 1961 até sua extinção em 1968, a AIA passou a desenvolver atividades de pesquisa no cerrado e atuar no desenvolvimento e colonização, acompanhando o contexto da expansão territorial para o centrooeste brasileiro. Em sua fundação, a AIA foi dividida em dois segmentos: um não lucrativo e outro lucrativo. Pouco mais tarde, em 1947, Nelson criou a International Basic Economy Corporation ${ }^{5}$ (IBEC), como braço lucrativo, deixando à AIA restrita as atividades filantrópicas (OLIVEIRA, 1999).

\footnotetext{
${ }^{3}$ Nelson Rockefeller também foi Governador de Nova Iorque entre 1959 a 1973 e o $41^{\circ}$ vice-presidente dos Estados Unidos da América, entre 1974 e 1977. Tentou algumas vezes, mas não conseguiu a indicação do Partido Republicano para Presidência (OLIVEIRA, 1999).

${ }^{4}$ Associação Internacional Americana para o Desenvolvimento Econômico e Social, em tradução literal.

${ }^{5}$ Corporação Internacional de Economia Básica, em tradução literal.
} 
Enquanto as equipes da AIA promoviam a criação de frangos, Nelson montava, através da IBEC, uma empresa de ração para aves. As equipes da AIA promoviam as virtudes dos fertilizantes químicos e a IBEC os vendia. A AIA encorajava o uso de sementes mais produtivas, a IBEC vendia sementes híbridas. A AIA pregou o evangelho dos pesticidas e herbicidas e a IBEC montou uma empresa de fumigação (COLBY; DENNETT, 1998, p. 251).

$\mathrm{Na}$ prática, a adoção deste modelo de extensão rural pelos países latino-americanos impulsionou a estratégia de ampliação dos mercados para a comercialização de "insumos, máquinas e equipamentos produzidos pelas indústrias norte americanas, ao mesmo tempo em que visava conter a expansão da influência do bloco de países socialistas na América Latina, no contexto da guerra fria" (ROS, 2012, p. 26). A última preocupação é evidenciada na última frase do primeiro relatório anual da ACAR-MG, publicado em 1950: "Esta é uma das respostas da democracia aos perigos que ameaçam os povos amantes da liberdade" (ACAR-MG, 1950, p. 12).

Por outro lado, a criação da ACAR-MG em 1948 foi beneficiada por um cenário político favorável: o interregno do nacional desenvolvimentismo de Vargas, refratário ao intervencionismo. Em 1948, o Presidente era o General Eurico Gaspar Dutra, militar liberal-conservador, que ao contrário da maioria dos seus pares, era surpreendentemente pragmático em assuntos de política externa e grande aliado do governo americano em assuntos econômicos e na guerra fria. Apesar da ausência de registros na literatura da ação direta do Presidente nas ações extensionistas, os precursores da ACAR encontraram um grande aliado no Governador de Minas Gerais Milton Campos, político liberal da União Democrática Nacional (UDN), que rompera com Vargas em 1945 para apoiar o golpe do General Dutra (COLBY; DENNETT, 1998; OLIVEIRA, 1999).

Observa-se, portanto, uma miríade de motivações e circunstâncias favoráveis ao início do serviço de extensão rural brasileira através da ACAR-MG: na esfera pública, os interesses americanos em promover o desenvolvimento rural na américa latina, em contraponto ao que consideravam uma ameaça comunista durante a guerra fria e, da parte brasileira, o reforço aos vínculos da política externa, fortalecidas durante a segunda guerra mundial. Na esfera privada, triunfaram os interesses econômicos estrangeiros e nacionais através da reprodução do capitalismo e, em grande escala, o grupo Rockefeller, em suas ações lucrativas através do IBEC. Não se pode subestimar a importância da concepção de mundo dos magnatas, que através de suas práticas filantrópicas, buscavam polir sua imagem de marca e também a necessidade de desviar ou neutralizar as aspirações de outras camadas sociais. Os filantropos priorizavam ajudar as comunidades onde fosse possível obter os melhores 
resultados. Esse princípio foi fundamental para a ACAR, que tinha como princípio trabalhar com os mais capazes, entre os pequenos agricultores.

Como já assinalado, do primeiro ano de funcionamento até meados da década de 1960, o papel da tecnologia era subjacente e o acréscimo da produção ocorria mediante expansão horizontal das fronteiras agrícolas. O enfoque implícito dado as tecnologias não negaram seu papel na difusão onde era inexistente:

Foi a ACAR que introduziu no meio rural mineiro os primeiros fertilizantes químicos e defensivos agrícolas, a vacina contra aftosa e o milho híbrido. Além de difundir a tecnologia, eles, inicialmente, tiveram também de comercializar esses produtos. As poucas casas comerciais existentes não tinham suporte financeiro para trabalhar nessa área, uma vez que estariam sujeitas a prejuízos. O comerciante arriscava-se a perder o estoque ou a vendê-lo muito lentamente, à medida que os técnicos de extensão conseguissem convencer os agricultores a usá-los, porque os agricultores não confiavam nesses produtos e não os compravam. Com o passar do tempo, já difundida a prática, a ACAR passou às casas comerciais a responsabilidade de fornecer aos agricultores defensivos e fertilizantes. E foi aí que a má fé desses comerciantes veio a dificultar o trabalho do Serviço de Extensão (SILVA; LIMA, 1984, p. 6)

As ações iniciais da ACAR, apesar de incipientes, promoveram mudanças culturais e comportamentais, particularmente no que tange a adoção de tecnologias pelos pequenos produtores rurais, desempenhando importante função na gestação da agricultura tecnológica e suas vicissitudes.

Em sintonia com a experiência estadunidense de extensão rural, criou-se a base estrutural de um projeto de caráter político-pedagógico, que buscava através de ações assistencialistas de legitimação, ensinar os produtores a ajudar a si mesmos. Nessa lógica, o público preferencial era o pequeno agricultor e sua família e o planejamento das ações, entre extensionista e produtores, era vertical ascendente, partindo do diagnóstico da situação, seguida pela especificação de alternativas baseadas nos objetivos das famílias assistidas e por fim, na tomada de decisão, geralmente elaborada pelos extensionistas e operacionalizada pela família. As ações extensionistas caracterizaram-se pela comunicação informal entre os extensionistas, produtores e sua família e pela integralidade da ação educativa - das práticas agrícolas à economia doméstica - para elevação do bem-estar social. $\mathrm{O}$ financiamento das práticas agrícolas e domésticas ocorria pela oferta do crédito rural supervisionado, direcionado aos mais capazes entre os pequenos produtores rurais, parte central do modelo (RODRIGUES, 1997).

As atividades foram iniciadas em 1949 em quatro localidades mineiras: Pedra Leopoldo, Santa Luzia, Ubá e Curvelo. Os escritórios locais funcionavam em instalações modestas, com equipes 
paritárias formadas por um engenheiro agrônomo, uma moça treinada em economia doméstica e auxiliar de escritório. No início da década de 1950, cada equipe dispunha de um veículo jeep universal, importado diretamente da Willy Overland Export Corporation of Toledo, Ohio, USA. Neste jeep, o agrônomo e a profissional de bem-estar social visitavam as propriedades rurais para diagnóstico da realidade; organização de reuniões comunitárias para levantar os problemas e ajustar as soluções viáveis; fazer demonstrações práticas e palestras visando aumentar a renda das famílias; mostrar às donas de casa boas práticas domésticas para melhorar a qualidade de vida da família; identificar lideranças para conseguir o apoio da comunidade, facilitando a adoção das tecnologias e ajudar pequenos agricultores a conseguirem o financiamento bancário através de planos de empréstimos supervisionados ${ }^{6}$ (ACAR-MG 1950; OLINGER 1996). O relato a seguir, presente no terceiro relatório anual da ACAR (1952) sobre as atividades desenvolvidas pelo escritório de Três Pontas, no Sul de Minas Gerais, exemplifica o cotidiano das atividades desenvolvidas à época pelos extensionistas agropecuários e de bem-estar social:

Antes das 8 da manhã, carregam o jeep com um equipamento de nivelamento de terreno, um pacote de sementes selecionadas, um pulverizador e material para ensinar melhorias no lar [...] Henrique acompanha Hilário ao curral onde lhe mostra como dar vermífugo aos porcos; depois passeia pela propriedade a fim de inspecionar as culturas e demonstrar como aplicar fertilizante nos cafeeiros, do monte de composto. Eunice examina o novo fogão a lenha construído com o empréstimo e explica à D. Geralda, esposa de Hilário, a necessidade de ferver a água para beber. Ensina-lhe também como preparar vários pratos à base de leite para as crianças. Henrique e Eunice escolhem um local para a horta doméstica e prometem levar sementes, com instruções de plantio, quando a terra já estiver preparada. [...]. Por volta da 1 hora da tarde, após um almoço rápido na cidade, Henrique e Eunice chegam à escola rural, em Santana da Vargem, onde Eunice dá duas aulas mensais a um grupo de quinze senhoras e moças. Enquanto Eunice ensina noções de enfermagem, Henrique visita o Dr. Alcides Araújo, um não mutuário, a quem está orientando quanto ao plantio em curvas de nível, cuidado das laranjeiras e à instalação de luz, fossas sanitárias e hortas para seus empregados. Eunice encerra a aula, anuncia uma sessão de cinema para a noite de terça-feira, a ser realizada na escola, e acompanha duas moças pela estrada a fora até suas casas, a fim de inspecionar as hortas por elas plantadas há algumas semanas atrás. [...] ao mesmo tempo, Eunice e diversas senhoras e moças se reúnem ao redor da mesa da sala de jantar, a fim de discutir problemas relacionados com a saúde, saneamento e puericultura, ou vão à cozinha onde aprendem a preparar verduras e legumes. [...] (ACAR, 1952, p. 9).

\footnotetext{
${ }^{6}$ O Crédito Rural Supervisionado (CRS), instituído em 1948 pela ACAR de Minas Gerais, foi uma modalidade de crédito direcionada a pequenos produtores rurais (minifundiários, arrendatários, parceiros e ocupantes) que, em função de não auferirem rendas suficientes para realizarem as práticas agrícolas e domésticas que aprendiam, não podiam se beneficiar plenamente do serviço de extensão. Em muitos casos, as operações creditícias apresentavam taxas de juros negativas (SOUZA, CAUME, 2008; RIBEIRO, 2000).
} 
Em resumo, as diretrizes do serviço de extensão rural pioneiro contemplavam a tarefa, o método e os instrumentos. A tarefa: melhorar o nível de vida rural em Minas Gerais. O método: ajudar a população rural a ajudar a si própria. Os instrumentos: crédito aos pequenos lavradores, assistência técnica e ensino coletivo, ministrado nas comunidades por um agrônomo e por uma supervisora doméstica (ACAR, 1952). A Tabela 1 mostra a evolução do quadro de pessoal e paridade aproximada entre extensionistas agropecuários e de bem-estar social.

TABELA 1. EVOLUÇÃO DO QUADRO DE PESSOAL DO SISTEMA BRASILEIRO DE EXTENSÃO RURAL (SIBER) (1956-1962)

\begin{tabular}{lccccccc}
\hline \multicolumn{1}{c}{ Profissionais/ano } & $\mathbf{1 9 5 6}$ & $\mathbf{1 9 5 7}$ & $\mathbf{1 9 5 8}$ & $\mathbf{1 9 5 9}$ & $\mathbf{1 9 6 0}$ & $\mathbf{1 9 6 1}$ & $\mathbf{1 9 6 2}$ \\
\hline EAGRO & 138 & 206 & 267 & 287 & 329 & 364 & 413 \\
\hline BES & 127 & 179 & 214 & 233 & 245 & 262 & 304 \\
\hline Outros & 0 & 0 & 0 & 0 & 0 & 0 & 0 \\
\hline Total & 265 & 385 & 481 & 520 & 574 & 626 & 717 \\
\hline EAGRO/BES & 1,09 & 1,15 & 1,25 & 1,23 & 1,34 & 1,39 & 1,36 \\
\hline $\begin{array}{l}\text { \% Outros } \\
\text { profissionais }\end{array}$ & 0,00 & 0,00 & 0,00 & 0,00 & 0,00 & 0,00 & 0,00
\end{tabular}

FONTE: adaptado de Rodrigues (1997, p.136).

Notas: EAGRO - Extensionista Agropecuário; BES - Extensionista de Bem-estar Social

Os resultados alcançados durante os três primeiros anos de trabalho causaram impressão tão favorável junto ao governo do estado, que em dezembro de 1951 o Governador Juscelino Kubitschek de Oliveira assinou novo convênio com a ACAR para renovação e expansão das atividades durante 1952 a 1954, com orçamento mais que duplicado em relação à verba anterior, permitindo a ampliação do número de escritórios locais e de produtores atendidos pelo crédito rural supervisionado. Desta feita, o governo estadual concedeu valor superior ao pago pela AIA, seguindo o plano originalmente traçado de transformar o programa em trabalho de responsabilidade do Governo Estadual, técnica e monetariamente, enquanto que a AIA gradativamente diminuiria seus custos para aplicar em outros empreendimentos semelhantes (ACAR-MG, 1951).

A criação da ACAR em Minas Gerais estimulou a multiplicação de associações congêneres em outras unidades da federação brasileira (Quadro 1), gerando a necessidade de uma estrutura capaz de coordenar e supervisionar as atividades das associações estaduais e também para promover o aporte de recursos federais e treinamento aos futuros extensionistas. Assim, surgiu em 1956, por iniciativa direta do Presidente Juscelino Kubitschek de Oliveira, a Associação Brasileira de Crédito 
e Assistência Rural (ABCAR), entidade de direito privado sem fins lucrativos, tratada na legislação como Sistema Brasileiro de Extensão Rural (SIBER) (RIBEIRO, 2000).

QUADRO 1 - EVOLUÇÃO DO SISTEMA BRASILEIRO DE EXTENSÃO RURAL - 1948-1974

\begin{tabular}{|c|c|}
\hline 1948 & ACAR-MG \\
\hline 1954 & ANCAR (CE, PE, BA) \\
\hline 1955 & ASCAR-RS, ANCAR (RN, PB) \\
\hline 1956 & ABCAR, ACARESC \\
\hline 1958 & ACAR-RJ \\
\hline 1957 & ACAR-ES \\
\hline 1959 & ACAR-GO, ACARPA \\
\hline 1962 & Transformação dos programas estaduais da ANCAR em associações autônomas, a \\
primeira em SE \\
\hline 1963 & ANCARs: autonomia de RN, AL, MA e BA \\
\hline 1964 & ANCARs: autonomia de PE, PB e CE \\
\hline 1965 & ACAR-Pará, ACAR-MT \\
\hline 1966 & ANCAR-PI, ACAR-AM \\
\hline 1967 & ACAR-DF \\
\hline 1968 & ACAR-AC \\
\hline 1971 & ACAR-RO \\
\hline 1972 & ACAR-RR \\
\hline 1974 & ACAR-AP \\
\hline
\end{tabular}

FONTE: Peixoto (2008, p. 19).

O final do ano de 1962 representou uma virada de página para a extensão rural brasileira, a despeito das ações assistencialistas da AIA terem persistido de forma acanhada até 1968 no Sistema Brasileiro de Extensão Rural. Os avanços na base técnica da agricultura e os planos governamentais, a começar pelo Plano Trienal de Desenvolvimento Econômico-social (1963-1965) ${ }^{7}$ proposto pelo Ministro do Planejamento Celso Furtado, no governo do Presidente João Goulart, estabeleceram diretrizes para aumentar a produção e a produtividade agropecuária. Por consequência, as instituições públicas e privadas envolvidas com a assistência técnica e extensão rural, financiadas pelo poder público, passaram a ser rigorosamente requeridas no cumprimento às diretrizes estabelecidas e a partir de então, as ações passaram a fazer parte de um planejamento global de desenvolvimento do país através de instrumentos sistematizados.

\footnotetext{
${ }^{7}$ O Plano Trienal foi uma tentativa de resposta política à disparada da inflação, que se encontrava em 1963 na taxa de $78,4 \%$, à deterioração do comércio externo e ao baixo crescimento do Produto Interno Bruto.
} 
Inaugurou-se então um novo modelo de extensão rural voltado à difusão tecnológica, financiadas pelo crédito rural orientado ${ }^{8}$, cujos principais beneficiários foram médios e grandes produtores rurais. De cunho tecnicista, as estratégias de desenvolvimento e intervenção negligenciavam questões culturais, sociais ou ambientais, direcionado prioritariamente suas ações aos aspectos técnicos da produção, em prejuízo das práticas de bem-estar social. O planejamento das atividades era vertical descendente, isto é, o diagnóstico, a eleição de prioridades e as decisões sobre o que fazer competiam aos extensionistas. A tecnologia cumpriu papel finalístico para aumentar a produtividade da terra e no trabalho (RODRIGUES, 1997).

Um traço marcante da mudança de orientação para modernizar a base técnica produtiva do setor agrícola acontece quando o número de contratos de crédito rural orientado supera pela primeira vez, em 1963, as operações com o crédito rural supervisionado. Outra marca inconteste foi a substituição das equipes casadas, formadas por um extensionista agropecuário e uma extensionista doméstica, por equipes especializadas compostas por agrônomos, veterinários e técnicos em agropecuária, superando o localismo e o missionarismo em prol das questões estritamente econômicas. Também se evidenciou significativa expansão do aparato institucional. A relação entre o número de extensionistas locais e o número de estabelecimentos agropecuárias, partiu de 1/6.965 em 1960, para 1/2.203 em 1970 até chegar em 1:618 em 1980. O percentual de municípios atendidos saltou de 10\% em 1960 para 40,2\% em 1960, chegando a 77,7\% em 1980 (Id, 1997). A Tabela 2 ilustra o crescimento do quadro de pessoal em relação ao período anterior (Tabela 1) e a quebra de paridade entre extensionistas agropecuários e de bem-estar social.

TABELA 2. EVOLUÇÃO DO QUADRO DE PESSOAL DO SISTEMA BRASILEIRO DE EXTENSÃO RURAL (SIBER) (1963-1975)

\begin{tabular}{lccccccccccccccccc}
\hline $\begin{array}{l}\text { Profissionais/ } \\
\text { Ano }\end{array}$ & $\mathbf{1 9 6 3}$ & $\mathbf{1 9 6 4}$ & $\mathbf{1 9 6 5}$ & $\mathbf{1 9 6 6}$ & $\mathbf{1 9 6 7}$ & $\mathbf{1 9 6 8}$ & $\mathbf{1 9 6 9}$ & $\mathbf{1 9 7 0}$ & $\mathbf{1 9 7 1}$ & $\mathbf{1 9 7 2}$ & $\mathbf{1 9 7 3}$ & $\mathbf{1 9 7 4}$ & $\mathbf{1 9 7 5}$ \\
\hline EAGRO & 463 & 604 & 735 & 1026 & 1297 & 1394 & 1578 & 1703 & 2128 & 2747 & 3351 & 3485 & 4665 \\
\hline BES & 327 & 387 & 509 & 709 & 858 & 844 & 848 & 836 & 806 & 872 & 887 & 818 & 887 \\
\hline Outros & 18 & 17 & 22 & 21 & 28 & 49 & 43 & 63 & 81 & 130 & 121 & 165 & 179 \\
\hline Total & 808 & 1008 & 1266 & 1756 & 2183 & 2287 & 2469 & 2602 & 3015 & 3749 & 4359 & 4468 & 5731 \\
\hline EAGRO/BES & 1,42 & 1,56 & 1,44 & 1,45 & 1,51 & 1,65 & 1,86 & 2,04 & 2,64 & 3,15 & 3,78 & 4,26 & 5,26 \\
\hline $\begin{array}{l}\text { \% Outros } \\
\text { profissionais }\end{array}$ & 2,23 & 1,69 & 1,74 & 1,20 & 1,28 & 2,14 & 1,74 & 2,42 & 2,69 & 3,47 & 2,78 & 3,69 & 3,12 \\
\hline
\end{tabular}

FONTE: adaptado de Rodrigues (1997, p. 136).

Notas: EAGRO - Extensionista Agropecuário; BES - Extensionista de Bem-estar Social

\footnotetext{
${ }^{8}$ O Crédito Rural Orientado (CRO), modalidade de crédito característica no difusionismo produtivista, direcionava-se a modernização do processo produtivo através do uso intensivo de capital. Seus principais beneficiários eram médios e grandes empresários rurais, e em alguns casos, pequenos produtores com renda suficiente para garantir a capacidade de pagamento e disposição de aceitar e receber orientação para incremento da produtividade de seu empreendimento agrícola (SOUZA; CAUME, 2008).
} 
$\mathrm{Na}$ esfera jurídico-institucional da transição de modelos, a Lei Delegada $\mathrm{n}^{\circ} 11$, de 11 de outubro de 1962 criou a Superintendência de Política Agrária (SUPRA), com atribuições também voltadas à assistência técnica e extensão rural:

Art. $2^{\circ}$ Compete à SUPRA colaborar na formulação da política agrária do país, planejar, promover, executar e fazer executar, nos termos da legislação vigente e da que vier a ser expedida, a reforma agrária e, em caráter supletivo, as medidas complementares de assistência técnica, financeira, educacional e sanitária, bem como outras de caráter administrativo que lhe venham a ser conferidas no seu regulamento e legislação subsequente (PEIXOTO, 2008).

Após o golpe civil-militar de $1^{\circ}$ de abril de 1964, as novas orientações foram aprofundadas e algumas modificações no aparato estatal foram realizadas para alçar o desenvolvimento rural aos moldes da modernização conservadora. Poucos meses após a ruptura institucional, o Presidente Humberto de Alencar Castello Branco promulgou a lei $\mathrm{n}^{\circ}$ 4.504, de 30 de novembro de 1964, que dispôs sobre o Estatuto da Terra, um marco do ordenamento agrário brasileiro. A lei extinguiu a SUPRA e criou o Instituto Nacional de Desenvolvimento Agrário (INDA), com a finalidade de promover o desenvolvimento rural nos setores da colonização, da extensão rural e do cooperativismo e o Instituto Brasileiro de Reforma Agrária (IBRA), com a atribuição de prestar assistência técnica integral aos projetos de reforma agrária, em colaboração com os órgãos estaduais. Em 1966, o Decreto n 58.382 , de 10 de maio de 1966 atribuiu ao INDA a coordenação das atividades de extensão rural e a execução dos serviços à ABCAR e ACAR`s a ela filiadas. Em 1970, o Decreto-Lei nº 1.110, de 09 de julho de 1970 extinguiu o IBRA, o INDA e o Grupo Executivo da Reforma Agrária (GERA) e criou o Instituto Nacional de Colonização e Reforma Agrária para assumir todas prerrogativas. Porém, o INCRA não conseguiu desempenhar a contento a responsabilidade de coordenar a extensão rural brasileira (PEIXOTO, 2008). As sucessivas mudanças no aparato institucional do Estado dedicado à coordenação do sistema para atender as concepções de cada período, passa desde então a ser uma característica pronunciada na historiografia da extensão rural.

O malogro do INCRA e a expansão do modelo difusionista foram determinantes para a estatização do SIBER. Assim, a Lei nº 6.126, de 06 de novembro de 1974 autorizou o Poder Executivo a criar a Empresa Brasileira de Assistência Técnica e Extensão Rural (EMBRATER), em substituição à ABCAR, com o intuito de integrar os órgãos estaduais, capacitar os extensionistas e apoiar financeiramente as instituições oficiais de assistência técnica, extensão rural e pesquisa agropecuária. Porém, o marco legal foi o Decreto $\mathrm{n}^{\mathrm{o}}$ 75.373, de 14 de fevereiro de 1975, que regulamentou o 
instrumento anterior. Com a progressiva estatização das ACAR`s e com a criação de empresas e outras estruturas de assistência técnica e extensão rural, a maior parte denominadas Empresas de Assistência Técnica e Extensão Rural (EMATER), o SIBER transformou-se no Sistema Brasileiro de Assistência Técnica e Extensão Rural (SIBRATER) (Id, 2008).

\section{O vácuo institucional: Neoliberalismo e ausência do Estado}

A década de 1980 ficou conhecida como a "década perdida" para os países da américa latina. No Brasil, a estagnação econômica = quando se verificou uma forte retração da produção industrial, hiperinflação e baixo crescimento do produto interno bruto $(\mathrm{PIB})=$ resultou em perda do poder de compra da população, aumento da dívida externa e um gigantesco déficit fiscal. Este período contrastou, sob o ponto de vista macroeconômico, com a década de 1970, quando ocorreu o chamado "milagre econômico brasileiro".

No plano político, grandes foram os reflexos gerados pela superação do período autoritário em 1985, entre elas, a reorganização dos movimentos sociais, inclusive do campo; o recrudescimento do movimento ambientalista e o ressurgimento do movimento da agricultura alternativa e suas vertentes (orgânica, natural, biológica e biodinâmica). Vários debates políticos e acadêmicos sobre agroecologia, reforma agrária e serviço público se multiplicaram e parte das demandas represadas por mais de duas décadas resultaram na Constituição Federal de 1988. O artigo 187 da carta magna, dedicado à política agrícola, alude à responsabilidade federal sobre a assistência técnica e extensão rural em seu quarto inciso.

Entre os extensionistas do SIBRATER é majoritária a percepção das consequências da modernização conservadora. Nesta época, para um considerável número de extensionistas, as ideias do educador Paulo Freire, escritas em seu exílio no Chile durante a reforma agrária que se iniciou em 1968 e divulgadas em seu livro "Extensão ou comunicação?” (FREIRE, 1983), exerceram forte influência no questionamento da práxis extensionista. Na obra, Freire promove análise semântica da palavra extensão, em seus sentidos de base e contextual, para propor a ruptura com o seu significado e sua substituição pelo termo comunicação. Para o autor, extensão significa estender conhecimentos e técnicas agrícolas a alguém que não as possui. Portanto, só teria sentido se considerássemos a 
educação como prática de domesticação, ou da dominação como invasão cultural $^{9}$, em atitude contrária ao diálogo, base da educação libertadora.

Ao contrário, educar e educar-se, na prática da liberdade, é tarefa daqueles que sabem que pouco sabem - por isto sabem que sabem algo e pode chegar a saber mais - em diálogo com aqueles que, quase sempre, pensam que nada sabem, para que estes, transformando seu pensar que nada sabem em saber que pouco sabem, possa igualmente saber mais (FREIRE, 1983, p. 15).

Na ótica Freireana, a comunicação entre o agrônomo educador e os camponeses não deve se limitar a substituição acrítica dos conhecimentos empíricos pelas tecnologias, por maiores que sejam seus impactos sobre a produtividade. Em oposição aos "tradicionalistas" que defendem a manutenção do "status quo" e ao "messianismo tecnicista" caracterizado pela modernização mecânica das estruturas, o autor propõe a superação da simples assistência técnica, através da conscientização dos camponeses e da autoconscientização, para que procedimentos técnicos sejam oferecidos aos educandos como problemas que eles devem responder. Neste contexto, o agrônomo educador se insere com os camponeses na transformação da realidade através da dialogicidade, como sujeito com outros sujeitos, considerando sua bagagem cultural e as implicações sociais, técnicas e ambientais da ação.

$\mathrm{Na}$ efervescência política do cenário da redemocratização e com o esgotamento da orientação difusionista, esboçou-se no âmbito da EMBRATER e dos debates da sociedade civil, a adoção de um modelo de extensão rural fundamentado nos ideais de Freire, mas sem a ruptura com a expressão "extensão". Pretendia-se a promoção humana e integral das maiorias demográficas do campo, onde a relação, outrora vertical entre extensionistas e camponeses, se transformasse em relacionamento dialógico horizontal, com o protagonismo do produtor expresso em sua capacidade de problematizar a realidade e decidir.

Contudo, a resistência de setores fortalecidos no pós-redemocratização; o endividamento público e os objetivos do Ministério da Agricultura, focados na maior eficiência tecnológica para obtenção de safras recordes, suplantaram as demandas dos movimentos sociais em ascensão. Seguindo as exigências dos organismos financeiros internacionais, a EMBRATER, em movimento ensaiado desde 1989 pelo Governo Sarney, na conhecida operação desmonte, sem êxito em função da pressão política e corporativa, foi extinta em ampla reforma administrativa conduzida em 15 de março de 1990, primeiro dia do Governo do Presidente Fernando Collor de Mello, juntamente com

\footnotetext{
${ }^{9}$ Para Freire (1983), é a invasão, pelo extensionista, do espaço histórico-cultural responsável pela visão do mundo dos sujeitos, sobrepujando novo sistema de valores. Próprio do caráter antidialógico do termo "extensão".
} 
outras estatais, sob a alegação de que suas ações não interferiam diretamente nas dinâmicas sociais por não ofertar serviços diretos aos agricultores (ROS, 2012). Em resposta, as organizações estaduais de assistência técnica e extensão rural criaram seis dias após a Associação Brasileira das Entidades Estaduais de Assistência Técnica e Extensão Rural (ASBRAER).

A partir da extinção da EMBRATER, a extensão rural brasileira passou por um período de vácuo institucional, caracterizado pelas sucessivas mudanças nos órgãos responsáveis pela coordenação central e no absenteísmo do governo federal em sua responsabilidade constitucional. Por consequência, ocorreu desorganização em todo o sistema oficial nos estados, provocando fusões, extinções, mudanças de regime jurídico, sucateamento e, especialmente, a ausência de organicidade e articulação entre as instituições realizadoras do serviço. Embora a disposição constitucional estabeleça, o Decreto $\mathrm{n}^{\circ}$ 99.180, de 15 de março de 1990, que dispôs sobre a organização e funcionamento dos órgãos subordinados à Presidência da República, abortou completamente da competência federal a assistência técnica e extensão rural. De forma contraditória, poucos dias após, a Lei $n^{\circ}$ 8.028, de 12 de abril de 1990 restabeleceu a assistência técnica e extensão rural entre as competências do Ministério da Agricultura e Reforma Agrária (MARA) (PEIXOTO, 2008).

O Quadro 2 apresenta as contínuas mudanças nos órgãos federais responsáveis pela coordenação central do Sistema Brasileira de Assistência Técnica e Extensão Rural entre 1990 e 2003.

QUADRO 2. ÓRGÃOS FEDERAIS RESPONSÁVEIS PELA COORDENAÇÃO DO SISTEMA BRASILEIRO DE EXTENSÃO RURAL (1990-2003).

\begin{tabular}{|c|c|c|c|}
\hline Ano & $\begin{array}{l}\text { Órgão com prerrogativa } \\
\text { de estrutura central }\end{array}$ & $\begin{array}{l}\text { Instrumento } \\
\text { normativo }\end{array}$ & Observações \\
\hline 1990 & $\begin{array}{l}\text { Empresa Brasileira de } \\
\text { Pesquisa Agropecuária } \\
\text { (EMBRAPA), }\end{array}$ & Decreto $n^{\circ} 99.616$ & $\begin{array}{l}\text { A EMBRAPA criou secretaria específica } \\
\text { para a nova função (Secretaria de } \\
\text { Assistência Técnica e Extensão Rural), } \\
\text { porém não conseguiu cumprir o mesmo } \\
\text { papel. }\end{array}$ \\
\hline 1993 & $\begin{array}{lr}\text { Secretaria } & \text { de } \\
\text { Desenvolvimento Rural } \\
\text { (SDR) pertencente ao } \\
\text { Ministério da Agricultura, do } \\
\text { Abastecimento e da Reforma } \\
\text { Agrária (MAARA) }\end{array}$ & Decreto $^{\circ} 936$ & Reingresso na estrutura ministerial. \\
\hline 1994 & $\begin{array}{l}\text { Departamento de Assistência } \\
\text { Técnica e Extensão Rural } \\
\text { (DATER) pertencente ao } \\
\text { MAARA. }\end{array}$ & Decreto $\mathrm{n}^{\circ} 1.261$ & $\begin{array}{l}\text { O Departamento foi } r \text { criado } \\
\text { especificamente para as ações de } \\
\text { assistência técnica e extensão rural. As } \\
\text { ações foram limitadas pela carência de } \\
\text { recursos e pouca representatividade } \\
\text { política dos setores executores. }\end{array}$ \\
\hline 1998 & $\begin{array}{l}\text { Departamento de Assistência } \\
\text { Técnica e Extensão Rural } \\
\text { (DATER) pertencente ao }\end{array}$ & Decreto $\mathrm{n}^{\circ} 2.681$ & $\begin{array}{l}\text { Foi criado um gabinete específico para a } \\
\text { política fundiária, alterando a designação } \\
\text { do ministério. }\end{array}$ \\
\hline
\end{tabular}




\begin{tabular}{|l|l|l|l|}
\hline & $\begin{array}{l}\text { Ministério da Agricultura e } \\
\text { do Abastecimento (MAA). }\end{array}$ & & \\
\hline \multirow{3}{*}{2000} & $\begin{array}{l}\text { Secretaria de Apoio Rural e } \\
\text { Cooperativismo (SARC), } \\
\text { vinculada ao MAA }\end{array}$ & $\begin{array}{l}\text { Decreto n }{ }^{\circ} 3.527 \\
\text { Foi criado dentro da secretaria, o } \\
\text { Departamento de Infraestrutura e } \\
\text { Extensão Rural (DIER), a quem competia } \\
\text { promover e acompanhar a } \\
\text { operacionalização do SIBRATER }\end{array}$ \\
\hline
\end{tabular}

FONTE: Informações extraídas de Peixoto (2008)

As mudanças sucessivas na coordenação do sistema apontam para ausência deliberada do Estado na política de extensão rural. Entre os fatores fundamentais dessa crise, a opção por um modelo de desenvolvimento praticado em resposta a crise do capitalismo mundial, favorecida pela crescente integração das economias e sociedades dos vários países, especialmente no que tange à produção de mercadorias e serviços, mercado financeiro e difusão de informações. $\mathrm{O}$ advento de novas tecnologias comunicacionais e de processamento de dados impulsionou essa integração, denominada "globalização".

Seguindo o receituário inicialmente adotado pelo Presidente dos Estados Unidos, Ronald Reagan e pela primeira ministra do Reino Unido, Margaret Thatcher, na década de 1980, o governo do Presidente Fernando Henrique Cardoso aprofundou as ações iniciadas pelo Presidente Fernando Collor de Mello e implantou políticas voltadas a menor presença do Estado na economia para alcançar o equilíbrio fiscal.

A conciliação do Estado mínimo com o mercado soberano, adotado em vários países nas décadas de 1980 e 1990 ficou conhecida como "neoliberalismo". Este modelo, cortou gastos do Estado, particularmente os sociais e transferiu ao setor privado e filantrópico muitas das suas atribuições, inclusive promovendo privatizações do patrimônio público. Essa nova roupagem do liberalismo alavancou a crise do Estado de bem-estar social através do enfraquecimento e menor presença do poder central.

A ascensão do ideário neoliberal trouxe consequências deletérias à política de extensão rural, fazendo com que diversas instituições estaduais passassem a depender quase exclusivamente dos minguados repasses federais. Simultaneamente, ganha ênfase a discussão sobre a execução de políticas e programas por organizações não governamentais (ONG`s) e o crédito rural disponível aos produtores foi reduzido significativamente, prejudicando as ações de assistência técnica e extensão rural que encontram no mesmo um recurso metodológico de trabalho fundamental. Contudo, é importante ressaltar que não ocorreu a completa extinção do crédito. Por um lado, os monocultivos voltados à exportação e industrialização encontraram fartas linhas de financiamento. Por outro, tendo em vista as ações que legitimaram a agricultura familiar como categoria de análise, o governo do 
Presidente Fernando Henrique Cardoso criou o Programa Nacional de Fortalecimento da Agricultura Familiar (PRONAF), através do Decreto nº 1.946, de 28 de junho de 1996 (PEIXOTO, 2008). Já em seu primeiro desenho, o PRONAF forneceu crédito de investimento e custeio com forte subsídio, período de carência e elegibilidade exclusiva aos agricultores familiares.

\section{Ensaio de uma política voltada a educação integral, libertadora e humanista}

Em $1^{\circ}$ de janeiro de 2003 tomou posse o Presidente Luiz Inácio Lula da Silva, após campanha vitoriosa nas eleições de 2002. À esquerda no espectro ideológico em relação ao seu antecessor, sua eleição afetou as expectativas dos mercados, fazendo com que o risco brasil, índice criado para representar o grau de risco de se investir no país em determinado momento, disparasse ao final de 2012. Ainda antes da posse, o candidato Lula se viu obrigado a editar a "Carta ao povo brasileiro"10 onde propôs um novo contrato social, capaz de assegurar o crescimento com estabilidade. Na prática, a carta representou um grande aceno aos mercados e foi o embrião da política de conciliação de classes que marcou os governos do Partido dos Trabalhadores (PT).

$\mathrm{Na}$ maior parte do seu primeiro mandato, manteve inalteradas as políticas macroeconômicas do governo anterior, fundadas no famoso tripé composto pela política monetária (metas de inflação), câmbio flutuante e política fiscal (para gerar superávit primário). Após os ajustes realizados entre 2013-2015, surgiu uma nova proposta de política macroeconômica acompanhada de políticas assessórias (crédito, industrial etc.) que formaram uma unidade coerente capaz de substituir as políticas neoliberais originais. Os autores dessa proposta a denominaram "neodesenvolvimentismo". Em síntese, trata-se de uma política híbrida, que mescla as políticas macroeconômicas neoliberais com políticas de crédito, de estímulo ao consumo e assistência social. A adoção dessa via ocorreu em 2006 e caracterizou o governo até o encerramento do segundo mandato em 2010 (MORAIS; SAADFILHO, 2011). O mesmo caminho foi adotado pela sucessora, Dilma Vana Rousseff, mas percalços de ordem política e econômica não permitiram que a estratégia refletisse em indicadores tão bemsucedidos quanto os obtidos pelo governo Lula.

Ainda em 2000, no governo Fernando Henrique Cardoso, a Medida Provisória $\mathrm{n}^{\circ}$ 1.911-12, de 25 de novembro de 1999, transformou o Gabinete do Ministro de Estado Extraordinário de Política Fundiária, criado para atenuar os conflitos no campo, em Ministério da Política Fundiária e

\footnotetext{
${ }^{10}$ Disponível em: http://www1.folha.uol.com.br/folha/brasil/ult96u33908.shtml
} 
Agricultura Familiar. Em seguida, o nome foi alterado por Medida Provisória para Ministério da Política Fundiária e do Desenvolvimento Agrário. Por fim, outra Medida Provisória promulgada no mesmo ano adotou o nome que se estendeu durante os governos Lula e Dilma: Ministério do Desenvolvimento Agrário (MDA) (PEIXOTO, 2008). Criou-se um ministério específico para a agricultura familiar, deixando o Ministério da Agricultura, Pecuária e Abastecimento (MAPA) exclusivo à agricultura patronal. A separação de ministérios evidenciou a estratégia do governo Lula, não tão distante do governo anterior. Apesar do aumento significativo de recursos destinados ao Plano Safra da Agricultura Familiar, elaborado pelo MDA, continuaram diferenças desproporcionais de recursos em relação ao Plano Agrícola e Pecuário, sob a responsabilidade do MAPA. A Tabela 3 ilustra a diferença.

TABELA 3 - EVOLUÇÃO DO ORÇAMENTO DESTINADO AO CRÉDITO RURAL PARA AGRICULTURA FAMILIAR E AGRICULTURA EMPRESARIAL (EM BILHÕES DE REAIS) ${ }^{1}$

\begin{tabular}{cccc}
\hline Safra & $\begin{array}{c}\text { Agricultura Familiar } \\
(\mathbf{A})\end{array}$ & $\begin{array}{c}\text { Agricultura empresarial } \\
(\mathbf{B})\end{array}$ & B/A \\
\hline $\mathbf{2 0 0 2 / 2 0 0 3}$ & 2,30 & 20,00 & 8,70 \\
\hline $\mathbf{2 0 0 3 / 2 0 0 4}$ & 3,50 & 27,15 & 7,76 \\
\hline $\mathbf{2 0 0 4 / 2 0 0 5}$ & 4,60 & 39,45 & 8,58 \\
\hline $\mathbf{2 0 0 5 / 2 0 0 6}$ & 6,40 & 44,35 & 6,93 \\
\hline $\mathbf{2 0 0 6 / 2 0 0 7}$ & 7,10 & 50,00 & 7,04 \\
\hline $\mathbf{2 0 0 7 / 2 0 0 8}$ & 8,10 & 56,00 & 6,91 \\
\hline $\mathbf{2 0 0 8 / 2 0 0 9}$ & 10,40 & 65,00 & 6,25 \\
\hline $\mathbf{2 0 0 9 / 2 0 1 0}$ & 12,60 & 92,50 & 7,34 \\
\hline $\mathbf{2 0 1 0 / 2 0 1 1}$ & 13,30 & 100,00 & 7,52 \\
\hline $\mathbf{2 0 1 1 / 2 0 1 2}$ & 15,30 & 107,20 & 7,01 \\
\hline $\mathbf{2 0 1 2 / 2 0 1 3}$ & 18,60 & 115,00 & 6,18 \\
\hline $\mathbf{2 0 1 3 / 2 0 1 4}$ & 22,30 & 136,00 & 6,10 \\
\hline $\mathbf{2 0 1 4 / 2 0 1 5}$ & 24,10 & 156.10 & 6,48 \\
\hline $\mathbf{2 0 1 5 / 2 0 1 6}$ & 28,90 & 187,70 & 6,49 \\
\hline $\mathbf{2 0 1 6 / 2 0 1 7}$ & 30,00 & 185,00 & 6,17 \\
\hline 1Valores nominais. Os valores previstos em orçamento não coincidem com os valores liberados. \\
FONTE: Plano safra da Agricultura Familiar (2002/2003-2016/2017) e Plano Agrícola e Pecuário $(2002 / 2003-$
\end{tabular}

2016/2017).

Os recursos creditícios destinados aos agricultores patronais superaram os voltados à agricultura familiar em 610\% a 870\%. Paradoxalmente, os dados do Censo Agropecuário de 2006 nos mostram que o Valor Bruto de Produção (VBP) da agricultura patronal (R \$ 89 bilhões) superam o da agricultura familiar ( $\mathrm{R} \$ 54$ bilhões) em apenas 65\%. Ao mesmo tempo, a agricultura familiar é responsável por $74,4 \%$ das pessoas ocupadas (12,3 milhões de pessoas), enquanto a agricultura patronal absorve 25,6\% (4,2 milhões de pessoas) da força de trabalho (ASBRAER, 2014). 
Quanto ao referencial de política pública de extensão rural, após hiato de treze anos, o Departamento de Assistência Técnica e Extensão Rural (DATER) pertencente à Secretaria da Agricultura Familiar (SAF), do Ministério do Desenvolvimento Agrário (MDA), através do Decreto $\mathrm{n}^{\mathrm{o}} 4.739$, de 13 de junho de 2003, assumiu as prerrogativas de estrutura central para coordenar os serviços dos órgãos estaduais de extensão. A política foi inicialmente elaborada em 2001, através da da Resolução $n^{\circ}$ 26, de 28 de novembro de 2001, do Conselho Nacional de Desenvolvimento Rural Sustentável, que aprovou a Política Nacional de Assistência Técnica e Extensão Rural para a Agricultura Familiar, no âmbito do MDA, dez anos depois do plano elaborado pela Embrapa, quando estava sob sua responsabilidade a coordenação do SIBRATER (PEIXOTO, 2008). Em maio de 2004 foi publicada a primeira versão da Política Nacional de Assistência Técnica e Extensão Rural (PNATER), após amplos debates com a sociedade civil, realizados em quatro oficinas regionais e uma nacional, durante o ano de 2003. Desde sua origem, a PNATER orienta a adoção de novos enfoques metodológicos participativos, do paradigma tecnológico da agroecologia e da valorização do conhecimento nativo, também conceituado como tradicional ou local (DIAS et al, 2008). A PNATER também busca "apoiar ações específicas voltadas à construção da equidade social e valorização da cidadania, visando à superação da discriminação, da opressão e da exclusão de categorias sociais, tais como as mulheres trabalhadoras rurais, os quilombolas e os indígenas" (BRASIL, 2004, p.8).

Em sintonia com os novos referenciais global neodesenvolvimentista e setorial de desenvolvimento rural, a PNATER busca desde o início romper com as abundantes e desconformes definições de extensão referenciadas técnica e culturalmente no messianismo importado e no tecnicismo da modernização conservadora. A previsão legal para as metodologias participativas demarca a opção do Estado frente à veemente contenda semântica oriunda do uso corrente da expressão "extensão" e suas implicações diretas sobre a práxis empreendida nas dinâmicas sociais. Malgrado a política não tenha enfrentado a superação do vocábulo extensão, dado o seu alto grau de enraizamento institucional $^{11}$; as bases epistemológicas legitimadas por efeito da política se opõem à lógica transmissiva, manifesta na substituição mecânica e acrítica dos saberes previamente existentes pela introjeção do sistema de valores do extensionista e dos formuladores da política,

\footnotetext{
${ }_{11}$ Merece destaque o fato de programas de pós-graduação (Mestrado e Doutorado em Extensão Rural oferecidos pela Universidade Federal de Viçosa, Universidade Federal Rural do Pernambuco e Universidade Federal de Santa Maria; Mestrado em Desenvolvimento Sustentável e Extensão, promovido pela Universidade Federal de Lavras), publicações acadêmicas, a atual política nacional (PNATER) e inclusive o tripé no qual estão assentadas as instituições de ensino superior (ensino, pesquisa e extensão) ainda fazem uso do vocábulo.
} 
independentemente da legitimidade científica e dos resultados alcançados. Esta concepção literal de extensão é caracterizada por um processo comunicacional vertical, do extensionista que transmite um conteúdo fechado para o camponês, que pode inclusive assimilar o conhecimento, mas sem acomodar e reelaborar devido à inobservância aos seus saberes prévios, tornando-o um dependente técnico, cultural e comportamental dos agentes externos e reprodutor da ordem econômica e social estabelecida. Por outro lado, o viés contemporâneo de extensão proposto pela política - a despeito da inexistência de campo associativo na análise semântica da palavra que o sustente - compreende um processo de comunicação circular, de quem compartilha e constrói algo na perspectiva do diálogo; tendo como ponto de partida a situação concreta, a realidade e o meio existencial. As mesmas bases sustentam a práxis educativa alicerçada na reflexão e ação dos homens sobre o mundo para transformá-lo, para que através do embate dialético entre ação e reflexão ocorram mudanças na consciência humana sobre a estrutura social a qual estão imersos, permitindo uma aproximação crítica e reflexiva da realidade a ser estudada.

Nos três anos que sucederam a implementação da política, convênios e contratos foram firmados com centenas de entidades, com destaque para as 27 organizações públicas estaduais de ATER, baseadas nas diretrizes da PNATER. No período, diversos eventos de capacitação foram realizados e o orçamento federal destinado à extensão rural cresceu doze vezes (CAPORAL; RAMOS, 2006).

A Lei Federal 12.188, de 11 de janeiro de 2010, alterou o nome da política, que passou a ser denominada Política Nacional de Assistência Técnica e Extensão Rural para a Agricultura Familiar e Reforma Agrária (PNATER) e institucionalizou o Programa Nacional de Assistência Técnica e Extensão Rural na Agricultura Familiar e na Reforma Agrária (PRONATER). Nessa nova versão, às entidades e aos órgãos públicos e oficiais de Assistência Técnica e Extensão Rural continuaram a ser priorizados na captação de recursos. Para participar das chamadas públicas (que surgiram em substituição aos convênios), as unidades da federação firmam termo de adesão com o MDA, através do seu conselho de desenvolvimento rural sustentável. Os objetos contratados são definidos pelo MDA e pelo INCRA, quando se trata de beneficiários da reforma agrária. Para garantir celeridade na concessão dos recursos, a lei modificou o artigo 24 da Lei Federal n 8.666, de 21 de junho de 1993, que dispõe sobre a dispensa de licitação.

Dados de 2014 da ASBRAER demonstram que as instituições de assistência técnica e extensão rural estão presentes em $91 \%$ dos municípios brasileiros, atendendo 2,3 milhões de beneficiários, o que corresponde à 53\% dos agricultores familiares. A Tabela 4 apresenta o número 
de escritórios, técnicos de campo, o total de agricultores familiares em cada região brasileira e a relação entre agricultores familiares e técnicos de campo.

TABELA 4 - DADOS DAS INSTITUIÇÕES DE ASSISTÊNCIA TÉCNICA E EXTENSÃO RURAL NO BRASIL EM 2014.

\begin{tabular}{cccccc}
\hline Região & $\begin{array}{c}\text { Total de } \\
\text { municípios }\end{array}$ & $\begin{array}{c}\mathbf{N}^{\circ} \text { de } \\
\text { escritórios }\end{array}$ & $\begin{array}{c}\mathbf{N}^{\circ} \text { de técnicos } \\
\text { de campo }\end{array}$ & $\begin{array}{c}\text { Total de } \\
\text { agricultores } \\
\text { familiares (AF) }\end{array}$ & AF/Técnicos \\
\hline Norte & 449 & 455 & 2.910 & 413.101 & 142 \\
\hline Nordeste & 1.794 & 1.344 & 4.826 & $2.187,295$ & 454 \\
\hline Sudeste & 1.668 & 1.594 & 3.082 & 699.978 & 228 \\
\hline Centro-oeste & 466 & 449 & 1.303 & 217.531 & 167 \\
\hline Sul & 1.188 & 1.213 & 3.478 & 819.997 & 236 \\
\hline Total & 5.565 & 5.055 & 15.599 & 4.337 .902 & 279 \\
\hline
\end{tabular}

FONTE: ASBRAER (2014)

Outra informação relevante refere-se à participação dos recursos do PRONATER no orçamento das instituições estaduais de Assistência Técnica e Extensão Rural, em 2010. Dos R\$ 1,7 bilhões de orçamento total, 79,2\% dos recursos foram pagos pelo governo estadual; 7,5\% destinados pelo governo federal; $5,2 \%$ do governo municipal; $4 \%$ da prestação de serviços; 3,5\% de outras receitas e 0,5\% oriundos de convênios internacionais (ASBRAER, 2014). Em setembro de 2010, durante os debates para as eleições presidenciais, a Associação Brasileira das Entidades Estaduais de Assistência Técnica e Extensão rural (ASBRAER) encaminhou aos presidenciáveis um sumário executivo ${ }^{12}$ intitulado "Contribuição da Extensão Rural Estatal aos candidatos à Presidência da República" com cinco propostas para o setor. Entre elas, a sugestão que o governo aumentasse o aporte dos recursos, dos 7,5\% registrados em 2010 para $50 \%$.

\section{Considerações finais}

A análise da trajetória do referencial de política pública de extensão rural, frente as concepções globais e setoriais nos permitem concluir que as mudanças do enfoque na política, refletidas nas legislações, orientações filosóficas e base material, acompanharam os padrões de desenvolvimento, estreitamente influenciados pela conjuntura internacional e pelas sucessivas rupturas institucionais no Brasil, do assistencialismo ao difusionismo, passando pelo vácuo institucional e deste ao ensaio

\footnotetext{
${ }^{12}$ Disponível em: http://www.asbraer.org.br/arquivos/bibl/5-documento_asbraer_sumario_executivo.pdf
} 
de uma política voltada a educação integral, libertadora e humanista. O Quadro 3 apresenta uma síntese explicativa da relação direta entre os referenciais global, setorial e de políticas públicas para a extensão rural brasileira.

QUADRO 3. INTERFACES ENTRE OS REFERENCIAIS GLOBAL, SETORIAL E DE POLÍTICAS PÚBLICAS PARA A EXTENSÃO RURAL BRASILEIRA.

\begin{tabular}{|c|c|c|c|}
\hline Período & Referencial global & Referencial setorial & Referencial de políticas públicas \\
\hline $1948-1985$ & $\begin{array}{l}\text { Liberal-conservador } \\
\text { Nacional- } \\
\text { desenvolvimentismo }\end{array}$ & $\begin{array}{l}\text { Assistencialista } \\
\text { Modernização } \\
\text { conservadora }\end{array}$ & $\begin{array}{l}\text { - Criação da ACAR (AIA e Governo de } \\
\text { Minas Gerais) (1948) } \\
\text { - Criação de associações congêneres em } \\
\text { outras unidades da federação (1954-1974). } \\
\text { - Origem da ABCAR (1956). } \\
\text { - Plano trienal de desenvolvimento (1963). } \\
\text { - Criação da EMBRATER em substituição } \\
\text { à `ABCAR (1974). } \\
\text { - Estatização das ACAR’s (década de } \\
\text { 1970) }\end{array}$ \\
\hline $1985-2003$ & Neoliberalismo & Vácuo institucional & $\begin{array}{l}\text { - Extinção da EMBRATER (1990). } \\
\text { - Criação do PRONAF (1996) }\end{array}$ \\
\hline $2003-2016$ & Neodesenvolvimentismo & $\begin{array}{c}\text { Desenvolvimento rural } \\
\text { sustentável }\end{array}$ & $\begin{array}{l}\text { - PNATER (Decreto 4.739/03) } \\
\text { - PNATER (Lei 12.188/10) }\end{array}$ \\
\hline
\end{tabular}

FONTE: Oliveira (1999); Peixoto (2008); Rodrigues (1997).

No início do primeiro momento histórico, procurou-se atender os mais capazes entre os pequenos agricultores através de ações inicialmente financiadas e controladas por uma associação filantrópica norte-americana. À época, o Presidente era o General Eurico Gaspar Dutra, militar liberal-conservador, que ao contrário da maioria dos seus pares, era surpreendentemente pragmático em assuntos de política externa e grande aliado do governo americano em assuntos econômicos e na guerra fria, o que favoreceu a disseminação de um modelo de extensão assistencialista. A despeito das ações produtivas e de bem-estar social terem apresentado resultados econômicos e sociais imediatos, especialmente entre os mutuários, o alcance foi limitado e a pedagogia empreendida tornava o agricultor e a sua família tecnologicamente dependente dos extensionistas, visto que os saberes prévios sempre existentes não eram reconstruídos ou ressignificados criticamente, tão somente substituídos pelos conhecimentos dos extensionistas. As pronunciadas motivações geopolíticas e econômicas colaboram para o entendimento de que a ação legitimadora foi mobilizada para cumprir múltiplos propósitos, entre eles, proteger a sociedade contra o risco que representava o comunismo em tempos de guerra fria; para que os magnatas pudessem polir sua imagem de marca por intermédio da filantropia numa controversa amálgama com a busca pela bem-aventurança $\mathrm{e}$ redenção dos pecados; e, não menos importante, com o objetivo de promover a expansão do capitalismo na América Latina e aumentar os lucros dos desbravadores, inaugurando assim a adoção 
de uma noção de "desenvolvimento rural" focada no determinismo econômico. Assim, a caridade foi o remédio utilizado contra os riscos representados pela pobreza. A partir do Plano Plurianual (1963), o Estado Brasileiro se reposiciona. A opção pela modernização se consolida nas políticas de extensão rural com a criação da EMBRATER em substituição à ABCAR em 1974, com a finalidade de incrementar a produção agrícola e industrial e superar os fatores considerados como fonte de "atraso" no meio rural. O difusionismo foi alçado como estratégia pedagógica para promover o encurtamento do tempo que intermedeia o lançamento de uma inovação e sua adoção coletiva pelos agricultores e, por este motivo, o modelo depositou forte ênfase na comunicação de mensagens motivadoras e persuasivas. Pelas circunstâncias históricas e objetivos manifestos, o público preferencial passa a ser formado por médios e grandes produtores rurais e, para isso, o aparato estatal dedicado a extensão rural se multiplica. Neste período, os benefícios alcançados subordinaram-se ao desempenho do trabalho, neste caso, de uma camada majoritariamente formada pela elite rural.

Em 1985, durante a redemocratização, muitos foram as iniciativas da sociedade civil, especialmente entre os extensionistas, para reorientar o Estado no sentido de uma pedagogia emancipadora de assistência técnica e extensão rural, contudo, a resistência de setores fortalecidos no pós-redemocratização; o endividamento público e os objetivos do Ministério da Agricultura, focados na maior eficiência tecnológica para obtenção de safras recordes, superaram as demandas dos movimentos sociais em ascensão. O neoliberalismo, caracterizado pela conciliação do Estado mínimo com o mercado soberano, cortou gastos do Estado, particularmente os sociais e transferiu ao setor privado e filantrópico muitas das suas atribuições. Neste período, a extensão rural brasileira passou por um período de vácuo institucional, com a extinção da EMBRATER e a sucessiva mudança dos órgãos responsáveis pela articulação da política em nível nacional. Em destaque nesse período, a criação do PRONAF, que a despeito do orçamento incipiente, foi importante para o fortalecimento da agricultura familiar.

O último momento caracteriza-se por tentativas redistributivas, oriundas de um novo referencial global neodesenvolvimentista e de um referencial de política pública voltado para o desenvolvimento rural sustentável nos vieses econômico, social e ambiental. Ampliou-se o portfólio de políticas voltadas para a agricultura familiar e através da PNATER, criou-se novas metodologias participativas, alicerçadas na dialógica problematizadora e no planejamento circular entre os agentes catalizadores e produtores rurais, e colocou na agenda pública o paradigma tecnológico da agroecologia e a valorização do conhecimento nativo, também conceituado como tradicional ou local, com ações específicas voltadas à construção da equidade social e valorização da cidadania, visando à superação da discriminação, da opressão e da exclusão de categorias sociais, tais como as mulheres 
trabalhadoras rurais, os quilombolas e os indígenas. As novas orientações buscam garantir amplos direitos sociais aos agricultores familiares através da política de extensão rural.

Percebe-se também, confirmando a hipótese de Rodrigues (1997) enunciada na introdução deste trabalho, a forte seletividade do Estado na formulação das políticas de extensão rural, ora voltadas para a acumulação, outrora focadas na legitimação. Nesta lógica, o primeiro momento descrito, de cunho assistencialista (1948-1962) teve forte apelo de legitimação por razões geopolíticas (frente à "ameaça comunista") e moldado pelas concepções filantrópicas e interesses privados de um grupo estrangeiro. Condicionado pelos novos paradigmas tecnológicos e pelo Plano Trienal no Governo João Goulart, que paradoxalmente sofreu um golpe militar por defender reformas estruturais de base, o segundo momento (1962-1985) pendeu fortemente para a acumulação capitalista, ganhando maior ênfase a partir da criação da EMBRATER em 1974 e com a estatização dos órgãos nos estados. Entre 1985 e 2003, quando predominou o vácuo institucional, o ciclo de acumulação se manteve através da atitude deliberada do Estado em não interferir (ou pouco interferir) na coordenação do SIBRATER. Por fim, a implementação da PNATER (2003), em base humanista, representou um ensaio de uma política voltada a educação integral, libertadora e humanista. Apesar da substantiva formulação pedagógica decorrente da política e dos esforços concentrados para sua implementação, os recursos destinados ainda são insuficientes para alterar efetivamente a dinâmica dos órgãos estaduais e o legado tecnicista das políticas prévias demandam tempo e esforços concentrados para que os novos paradigmas sejam ressignificados pelos profissionais e, por consequência, reproduzir em grande escala as diretrizes da política. Tendo em vista a noção neodesenvolvimentista e a política de conciliação de classes dos governos do PT, infere-se que as ações alternaram ou sincronizaram momentos de acumulação e legitimação.

\section{Referências}

ACAR-MG. Relatórios anuais. Belo Horizonte, 1949-1954.

ASBRAER. Assistência Técnica e Extensão Rural no Brasil: Um debate nacional sobre as realidades e novos rumos para o desenvolvimento do País. Brasília, 2014. Disponível em < www.asbraer.org.br/media/attachments/2018/06/18/apresentacao.pdf> Acesso em: 30 jul. 2018.

BRASIL. Lei Federal 12.188, de 11 de janeiro de 2010. Institui a Política Nacional de Assistência Técnica e Extensão Rural para a Agricultura Familiar e Reforma Agrária - PNATER e o Programa Nacional de Assistência Técnica e Extensão Rural na Agricultura Familiar e na Reforma Agrária PRONATER, altera a Lei $\mathrm{n}^{\circ}$ 8.666, de 21 de junho de 1993, e dá outras providências. Congresso Nacional, Brasília, 2010. 
BRASIL, Plano Safra da Agricultura Familiar. MDA, Brasília, 2002 - 2016.

BRASIL, Plano Agrícola e Pecuário. MAPA, Brasília, 2002 - 2016.

CAPORAL, F. R.; RAMOS, L.F. Da Extensão Rural Convencional à Extensão Rural para o Desenvolvimento Sustentável: Enfrentar desafios para romper a inércia.. In: MONTEIRO, D. M. C. e MONTEIRO, M. A.. (Org.). Desafios na Amazônia: uma nova Assistência Técnica e Extensâo Rural. 1ªed. Belém: UFPA/NAEA, 2006, v. 1, p. 27-50.

COLBY, G.; DENETT, C. Seja feita a vossa vontade. Rio de Janeiro: Record, 1998. 1060 p.

DIAS, C. E. A. et al. Enfoques metodológicos participativos e agroecologia na política nacional de assistência técnica e extensão rural. Revista de Ciências Agroveterinárias, v. 07, p. 48-53, 2008.

ESTEVA, G. Desenvolvimento. In: SACHS, W. Dicionário do desenvolvimento. Guia para o conhecimento como poder. Petrópolis: Vozes, 2000; p. 59-83.

FREIRE, P. Extensão ou Comunicação? $7^{\circ}$ ed. Rio de Janeiro, Paz e Terra, 1983. 93 p.

GRISA, C.; SCHNEIDER, S. Três gerações de políticas públicas para a agricultura familiar e formas de interação entre sociedade e Estado no Brasil. In: GRISA, C.; SCHNEIDER, S. (Orgs.) Políticas Públicas de Desenvolvimento Rural no Brasil. Porto Alegre: Editora da UFRGS, 2015. p. 19-50.

KAgEYamA, A. Desenvolvimento: conceito e medida. In: Cadernos de Ciência \& Tecnologia, Brasília, v. 21, n. 3, p. 379-408, set./dez. 2004.

MATOS, A. K. V. Revolução verde, biotecnologia e tecnologias alternativas. Cadernos da FUCAMP, Campinas v.10, n.12, p.1-17, 2010.

MORAIS, L.; SAAD-FILHO, A. Da economia política à política econômica: o novodesenvolvimentismo e o governo Lula. Rev. Econ. Polit. vol.31 no.4 São Paulo Oct./Dec. 2011.

NAVARRO, Z. Desenvolvimento rural no Brasil: os limites do passado e os caminhos do futuro. Estudos Avançados. USP, São Paulo, v.15, n.43, p. 83-100, dez. 2001.

OLINGER, G. Ascensão e decadência da extensão rural no Brasil. Florianópolis: EPAGRI, 1996. $523 \mathrm{p}$.

OLIVEIRA, M. M. As circunstâncias da criação da Extensão Rural no Brasil. In: Cadernos de Ciência \& Tecnologia, Brasília, v. 16, n. 2, p. 97 - 134, mai-ago: 1999.

PEIXOTO, M. Extensão rural no Brasil - uma abordagem histórica da legislação. Brasília: Senado Federal, 2008. (Textos para discussão 48). p. 25-44.

RIBEIRO, J. P. A saga da extensão rural em Minas Gerais. São Paulo, Annablume, 2000. 270 p. 
RODRIGUES, C. M. Conceito de Seletividade de Políticas Públicas e sua Aplicação no Contexto da Política de Extensão Rural no Brasil. In: Cadernos de Ciência \& Tecnologia, Brasília, v. 14, n. 1, 1997. p. 113-154.

ROS, C. A. Gênese, desenvolvimento, crise e reformas nos serviços públicos de extensão rural durante a década de 1990. Mundo Agrario (La Plata), v. 13, p. 1-40, 2012.

SCHNEIDER, S. Situando o desenvolvimento rural no Brasil: o contexto e as questões em debate. Revista de Economia Política, v.30, n.3, p.511-531, jul/set. 2010.

SILVA, M. C.; LIMA, A. L. O serviço de Extensão Rural em Minas Gerais (retrospectiva). Viçosa, Imprensa Universitária da Universidade Federal de Viçosa, 1984. 39 p.

SOUZA, C. B.; CAUME, D. J. Crédito Rural e Agricultura Familiar no Brasil. In: XLVI Congresso da Sociedade Brasileira de Economia, Administração e Sociologia Rural, 2008, Rio Branco. Anais do XLVI Congresso da Sociedade Brasileira de Economia, Administração e Sociologia Rural, 2008.

VEIGA, J.E. A face rural do desenvolvimento- natureza, território e agricultura. Porto Alegre: Editora Universidade/UFRGS, 2000. 197 p.

Artigo recebido em 16/10/2018. Aceito para publicação em 17/12/2018. 